\title{
Lovetown. Kilka uwag o angielskim tłumaczeniu Lubiewa
}

\author{
I am what I am \\ I don't want praise I don't want pity \\ I bang my own drum \\ Some think it's noise I think it's pretty
}

Gloria Gaynor

Lubiewo Michała Witkowskiego ${ }^{\mathrm{I}}$ to powieść niemalże kultowa, o której napisano już wiele (być może nawet za dużo), i która przez wielu literaturoznawców została uznana za najważniejszą polską książkę po 1989 r. Ku niezadowoleniu (choć zgodnie z przewidywaniami) samego autora Lubiewo okrzyknięto pierwszą powieścią ciotowską/gejowską. Książka ta wyznaczyła też swoistą cezurę, dzielącą literaturę gejowską na tę przed i tę po Lubiewie, i wpłynęła na nowe odczytywanie kanonicznych dzieł polskich pisarzy o „odmiennej orientacji”, takich jak Witold Gombrowicz czy - a może przede wszystkim - Miron Białoszewski. I chociaż po Lubiewie nastąpił wysyp powieści gejowskich lub zawierających wątki gejowskie, to żadnej z nich nie udało się powtórzyć sukcesu książki Witkowskiego (notabene na odpowiedź ze strony powieści lesbijskiej czekamy nadal). Żaden z pisarzy należących do tego środowiska nie zdobył również takiej (wręcz popkulturowej) sławy - toteż tylko Witkowski wielkim (nieheteronormatywnym, współczesnym, polskim) pisarzem jest i basta.

Choć Lubiewo ukazało się w 2005 r., jego fragmenty publikowano już wcześniej, a i o tym, że Witkowski tworzy (pierwszą! a jakże) powieść ciotowską, również było głośno w środowisku literackim. Entuzjastyczne przyjęcie książki przełożyło się na nominacje do wielu nagród (z których część Lubiewu przyznano), niejedną adaptację teatralną (w Polsce i za granicą), komiks, a także thumaczenia - między innymi ukraińskie (2006), rosyjskie (2007), niemieckie (2007), francuskie (2007), szwedzkie (2008), hiszpańskie (2011) oraz oczywiście angielskie (2010).

I M. Witkowski, Lubiewo, wyd. 3 popr. i uzup., Kraków 2005. Dalej cytaty $\mathrm{z}$ tego wydania oznaczam skrótem Lb, po którym podaję numer strony. 
„Każde wydanie Lubiewa jest inne” - tymi słowami autor rozpoczyna swą przedmowę do Lubiewa bez cenzury (2012), czyli w zasadzie siódmego wydania tejże powieści. Od 2005 r., kiedy to książka ukazała się po raz pierwszy, w ciągu raptem trzech lat na rynek weszło kolejnych pięć wydań. Witkowski powieść zmieniał i poprawiał (i - jak deklaruje - ma zamiar robić to nadal), wzbogacając przede wszystkim drugą część (Ciotowski bicz) historiami swoich czytelników, którzy sami tworzyli - właśnie: gejowską? ciotowską? - subkulturę PRL-u, a pewne wątki usuwając. I tu pojawia się już pierwsza trudność w przekładzie. Brak kanonicznej wersji sprawia, że wydane w 2010 r. angielskie tłumaczenie (wydanie drugie zaś w 2011 r.) nie jest w zasadzie tożsame z żadnym konkretnym wydaniem polskim. Jak pisze w Lubiereie bez cenzury Witkowski - część fragmentów, które nie ukazały się w poprzednich wydaniach polskich, weszła w skład wydań tłumaczonych ${ }^{2}$. Stanisława Barańczaka „ocalone w tłumaczeniu” możemy więc potraktować $\mathrm{w}$ tym wypadku zupełnie dosłownie.

Autorem przekładu angielskiego, Lovetown ${ }^{3}$, jest Bill Martin (podpisujący się W. Martin), niemalże równolatek samego Witkowskiego. Co ciekawe, urodzony w Nowym Jorku Martin jest wykładowcą na nowojorskim Colgate University, ale Lubiewo przetłumaczył dla stosunkowo nowego brytyjskiego wydawnictwa Portobello Books. Zauważmy ponadto, że książka ta charakteryzuje się też niejako dwoma stopniami obcości: jest obca, bo pisana w obcym języku, ale pierwiastek obcy wnoszą też bohaterki/bohaterowie (choć $\mathrm{z}$ punktu widzenia literatury zachodniej - właściwie nie są oni aż tak wyjątkowi) oraz specyfika świata przedstawionego, w którym rozgrywa się lub do którego nawiązuje fabuła powieści, czyli komunistyczny reżim. Ergo - występuje tu pewnego rodzaju nakładanie się kolejnych warstw osobliwości-obcości, można by zatem rzec, że zarówno powieść, jak i przekład oraz sam proces tłumaczenia naznaczone są - nomen omen - queerowością.

Co ważne, Lovetorem zaczyna się krótką notatką o autorze i tłumaczu, a kończy posłowiem thumacza. Postać Martina otwiera więc i zamyka całość, nie pojawia się jednak bezpośrednio (nawet przypisem) w samym tekście.

W posłowiu tłumacz zwraca uwagę na kilka problematycznych kwestii. Jako pierwszy bierze na warsztat wyraz „emerytka”.

${ }_{2}^{2}$ Lubiewo bez cenzury zawiera także pewną pomoc dla thumaczy w postaci słowniczka objaśniającego niektóre elementy rzeczywistości Polski Ludowej.

3 M. Witkowski, Lovetown, thum. W. Martin, Londyn 2010. Dalej cytaty $\mathrm{z}$ tego wydania oznaczam skrótem Lv, po którym podaję numer strony. 
Angielski odpowiednik, który wybiera, to old dear, emerytki Witkowskiego zachowują się bowiem jak starsze (chociaż bardzo rozwiązłe) panie. W tekście Martin używa sporadycznie także określenia lady pensioner, dopowiadając $\mathrm{w}$ ten sposób czytelnikowi brakującą informację o „statusie zawodowym” bohaterek.

Innym problemem omówionym przez Martina jest przekład słowa „luj”, które - co zabawne w kontekście samej książki pochodzi z gwary poznańskiej. Jak zauważa tłumacz, wyraz ten nie jest powszechnie używany w polskim gejowskim socjolekcie, przez co nie może zostać przetłumaczony na popularne wśród czytelników i czytelniczek anglojęzycznych trade. Martin wybiera więc rzeczownik grunt, oznaczający żołnierza szeregowca, co wydaje się trafne, jako że poczciwe emerytki są wyjątkowymi entuzjastkami przyjaźni polsko-radzieckiej i bratania się z sowieckimi żołnierzami.

Dość oczywisty problem stanowi przekład słowa „ciota”. Martin zwykle posługuje się tu określeniem queen, nie robi tego jednak konsekwentnie, zastępując je czasem rzeczownikami bomo, queer, faggot, fairy. Przy czym queen zdaje się przekładem najbardziej udanym, zwłaszcza w kontekście rozpoznawalnego przez docelowych czytelników idiomu, ponieważ odwołuje się do wybitnie transgresyjnego zjawiska - drag (queen). Ten dyskurs widoczny jest też na (swoją drogą świetnej) okładce wydania z 2011 r., zaprojektowanej przez Lindsay Nash: otwarte, umalowane usta, które zastępują literę „o” w tytułowym - town, mają konotacje seksualne, a oprócz tego kojarzą się także z początkiem na wskroś queerowego (i transowego) musicalu Recky Horror Picture Show.

W posłowiu Martin wyjaśnia też swój przekład tytułu drugiej części książki, Ciotowski bicz na The Lewd Beach, wskazując na etymologię przekształconego związku frazeologicznego - „rozpuszczony jak dziadowski bicz” - oraz specyfikę gry słownej polegającej na tym, że wymowa angielskich słów beach i bitch dla przeciętnego Polaka brzmi podobnie. Tłumacz zwraca także uwagę na wszechobecną w Lubiewie dychotomię (która stanowi prawdopodobnie dominantę przekładu): od podwójnych nazw miast (polskich i niemieckich: Wrocław - Breslau) począwszy, przez podwójne imiona (Michał - Michaśka), podwójne wykluczenie (homoseksualizm i bieda), po dwa różne światy i dwa sposoby mówienia (męski, żeński). Przepaść między tym, co oficjalne, a tym, co nielegalne i niebezpieczne - symbolizowana z jednej strony przez gejbar, z drugiej przez park/szalet. Dalej: nowoczesne i przestarzałe, zasymilowani i ci na marginesie, gdzie PRL-owskie cioty reprezentują tych drugich, a kapitalistyczni 
geje z Poznania - pierwszych ${ }^{4}$. Wyrażenie "grupa z Poznania” (Lb, s. 141) Martin tłumaczy zreszta jako the team from Poznan (Lv, s. 149), co od razu przywołuje skojarzenia chociażby z team work czy teamem sportowym, więc i pewnym poczuciem jedności wynikającym z realizowania wspólnych celów, które to poczucie jest podstawą tożsamości współczesnych ruchów $\operatorname{LGBT}(\mathrm{Q})$.

$\mathrm{Na}$ pochwałę zasługuje również lekkość języka przekładu. Popularne (a zarazem powszechnie - i słusznie - krytykowane przez przekładoznawców) kryterium „dobrze się czyta” jest w tym wypadku adekwatne, ponieważ Martinowi udaje się oddać tak ważną dla lektury Lubiewea sprawność pióra autora. Przekład angielski odznacza się płynnością, ciętym językiem i humorem, oferując tę samą grzeszną przyjemność czytania, co dzieło Witkowskiego. Martin dobrze wyczuwa również zmiany stylu i rejestru, lawirując między ironią i groteską a patosem i melancholią. Tłumaczowi udaje się odwzorować pewną triadę obecną w samym Lubiewie, którą tworzą niesamowite przygody, w tym kończące się tragicznie, osobiste dramaty jednostek takich jak Dianka (Di), oraz imaginacja i gra w udawanie. Równie dobrze zostaje uchwycona różnica między językiem kobiecym (zilustrowana np. w świetnym przekładzie podrozdziału $\mathrm{Ci}-\mathrm{Ci}-\mathrm{Ci}$, ang. $C b a-C b a-C b a)$ a męskim (tutaj zwłaszcza fragment Jak Anna podrywała luja na wspótczucie, ang. How Anna Got a Grunt to Pity-Fuck Her) oraz przeskoki od gawędziarskiego tonu, po niemalże naukowy $\mathrm{w}$ rozdziale Teoria przegięcia (ang. Theory of Swish). Momentami rozczarowuje niestety thumaczenie wypowiedzi stylizowanych na quasi-barokowe dialogi czy archaizowanych w inny sposób. W Lovetown brzmią one zbyt współcześnie oraz niedostatecznie literacko i kampowo.

Jednym z najważniejszych aspektów Lubiewa jest właśnie estetyka przegięcia. Próbując ją przełożyć, Martin sięga po idiom znany czytelnikowi docelowemu, jakim jest zachodni kamp. Przy czym wcale nie thmaczy „przeginania się” jako camp, lecz raczej swish (termin oznaczający nie tylko zniewieściałego mężczyznę, lecz także kołysanie biodrami z boku na bok, a więc specyficzny rodzaj kokieteryjnego poruszania się), a słowa camp używa właściwie tylko tam, gdzie robi to sam Witkowski lub jako zwrotu dookreślającego swish; podobnie postępuje z wyrazem dramatic - being dramatic (teatralizacja stanowi w zasadzie najbliższy synonim kampu, doskonale oddający aspekt odgrywania

4 Na marginesie: Poznań obecnie uważa się za swoistą mekkę gejów. I tu obok oficjalnych gejbarów i kawiarni gay-friendly występują miejsca, które pamiętają „tamte” czasy, obecnie już w zasadzie zapomniane, jak chociażby tzw. Park Pedała. 
roli i udawania). Dzięki temu w pewien sposób dystansuje się od akademickości dyskursu i skojarzeń zbyt artystyczno-estetycznych (popularny sposób obrazowania ciot w PRL-u to właśnie „albo balet, albo szalet”, przy czym bohaterki Lubiewa częściej chadzają do tego drugiego, dlatego i potoczny swish jest im bliższy niż camp). Martinowi udaje się zatem uchwycić kampowość świata skonstruowanego przez autora i oddać ją w przekładzie. Polski oryginał - chociażby ze względu na specyfikę samego języka (występowanie rodzaju gramatycznego) - zdaje się wręcz naturalnie i ostentacyjnie kampowy. W związku z tym Martin musi szukać środków, by wzmocnić, wydobyć kamp tłumaczenia. Robi to, przede wszystkim odwzorowując (chciałoby się powiedzieć - wiernie) cechy kampowego języka obecne już w Lubiewie, a więc pewnej formy stereotypowego (przegiętego właśnie) języka kobiet. $Z$ tego powodu tłumacz zachowuje wszelkie powtórzenia, wykrzyknienia, dramatyczne i hiperbolizujące zwroty, „ochy”, „achy”, zdrobnienia - wszystko, co wyraża intensywne emocje („Ależ przestań, moja droga!” - „Oh stop, darling!”; Lb, s. 13 / Lv, s. 8), a także odzwierciedla swoistą kwiecistość stylu: operowanie grami słownymi oraz wyzwiskami, którymi niby pieszczotliwie obrzucają się bohaterki. Rekompensując brak rodzaju gramatycznego, Martin wybiera określenia jak najbardziej naznaczone płciowością. Od siebie dodaje natomiast stosowanie kursywy jako formy emfazy. Podkreślanie fragmentów wypowiedzi, graficzne uwypuklanie pewnych słów dla odzwierciedlenia akcentu, jaki pada na nie w wymowie, to kolejny element zachodniego kampu.

W kwestii przekładu nazw własnych panuje pewna niekonsekwencja. Tłumacz część imion pozostawia w oryginale (np. Zdzisław, Michał), część tłumaczy fonetycznie (Dżesika Jessica), część w pełni, jak Sowa - Owl, a jeszcze inne zastępuje odpowiednikiem z języka docelowego (Śnieżka - Snow White i mniej udane - Snowflake). Dominuje jednak strategia nieprzekładania nazw własnych. Tłumaczeniu podlegają głównie pseudonimy odrzeczownikowe. Największa ingerencja Martina w tym zakresie to wprowadzenie imion quasi-francuskich tam, gdzie nie występują one w oryginale (Łucja Kąpielowa - Lucia La Douche, Piękna Helena - La Belle Helene, Lady Pomidorowa - Madame d'Aubergine, a także Michalina La Belletriste, czyli Michaśka Literatka). I mimo że zabieg (co ważne, obejmujący głównie nazwy własne matek założycielek ciotowskiej sceny Wrocławia) wydaje się dziwaczny, zbędny, a czasami wręcz zupełnie niezgodny $\mathrm{z}$ oryginałem ( $\mathrm{i}$ jego osławioną intencją), to taka strategia współgra ze wspominanym zwiększaniem kampowości tekstu. 
Dla czytelnika anglosaskiego francuski jest bowiem sam w sobie językiem przegiętym. Francuszczyzna ułatwia także tworzenie nazw żeńskich, jak piosenkarka - chanteuse - zamiast bezosobowego vocalist, singer.

Bill Martin stara się skrzętnie oddać też wszelkie podteksty, czasami w zabawny sposób wzbogacając powieść o swoje rozwiązania: „Those barracks on Barracks Street, we used to call them head-quarters (Lv, s. 18; w oryginale: „Te koszary na Koszarowej, to się nazywało: Komendantura” - Lb, s. 25). Język bohaterek przekładu pozostaje więc lubieżny5. Old dearsświntuszą tak samo jak emerytki i nie przepuszczą żadnej okazji, by powiedzieć jaką́s sprośność: „Lukrecja, idź po popielniczkę, bo pan nie ma gdzie strzepać (hi! hi!), strzepać... popioooooołu!” (Lb, s. 14); „Oh, go and get the ashtray, Lucretia, the gentelman has nowhere to put his (ha! ha!) aaaassshh!” (Lv, s. 8). Przejawem wzbogacania oryginału Witkowskiego jest też scena, w której bohaterki opisują proste, żartobliwe frazy, jakimi zwracały się do siebie nawzajem ku uciesze Matki Joanny od Pedałów kierowniczki knajpki „Mała Ciotka”: zwykłe „dam ci torebką po głowie” (Lb, s. 47) Martin zastępuje ripostą „that's what she said” " $(\mathrm{Lv}, \mathrm{s} .41)$, która jest klasycznym przykładem zamieniania pozornie niewinnego stwierdzenia $\mathrm{w}$ dwuznaczne, a więc i klasycznym przykładem kampowania tekstu.

Wyrazista ingerencja tłumacza pojawia się także w miejscu, w którym Michaśka opisuje rodzaje ciot. Jeden stanowią „Ciotki Reprezentantki Gejostwa Wobec Mediów, w skrócie: Ciotki Reprezentantki” - gdy Witkowski ewidentnie wyśmiewa tu polski medialny dyskurs gejowski, Martin idzie o krok dalej, Ciotka Reprezentantka to w jego przekładzie: „the Press Spokesperson for Lesbian, Gay, Bisexual, Intersex, Transgender, Queer and Questioning Community Queen, or LGBITQQ7 Queen for short”. Martin zdaje się zatem wbijać szpilę także queerowi, czyli temu, co na Zachodzie bardziej popularne, a więc czytelnikom anglojęzycznym bliższe, podkreślając absurdalność dodawania kolejnych literek do znanego skrótu. Taki zabieg również

\footnotetext{
5 Komiczny, choć to być może efekt wcale nie zamierzony, jest przekład „deszczowego kochanka” (czyli ekshibicjonisty, który onanizował się w parku) na Rainy Lover, ponieważ takie samo imię nosił słynny koń wyścigowy z tamtych lat.

${ }^{6}$ Bardzo udane wyjaśnienie tego zwrotu przedstawia internetowy Urban Dictionary - Example: „In the classroom, talking about a test. Student A „Wow, that's really hard!”, Student B „That's what she said!” (http: / / www.urbandictionary.com/define.php? term $=$ that $\% 27 \mathrm{~s} \% 20$ what $\% 20$ she $\% 20$ said $>$, dostęp: 22 maja 2013).

7 Ten „skrót” bywa czasem wzbogacany jeszcze o „A”, oznaczające allies.
} 
pokazuje pewną niemoc samego dyskursu queer, który powoli staje się - wbrew pierwotnym założeniom - swoistym workiem pełnym licznych, choć w praktyce mało przydatnych, przyjmowanych niejednokrotnie bezkrytycznie terminów i konceptów, które nadal nie oddają skomplikowania tożsamości seksualnej.

Łatwość w operowaniu wulgaryzmami i bogactwo języka erotycznego, z jakim oswojony jest czytelnik anglojęzyczny, powoduje, paradoksalnie, że Lovetown zdaje się mniej wulgarne niż Lubiewo (które Dariusz Nowacki w swojej niesławnej już recenzji nazwał zresztą wręcz „przeraźliwie wulgarnym”). Wrażenie to wspiera sam Martin, kiedy w thumaczeniu pomija wulgaryzmy, przerabiając na przykład „obciąganie” na fellatio, „pedałów” na bomosexuals, a „kurwę” na streetwalker. Ważna jest tu refleksja samego narratora, który zastanawiając się nad językiem adekwatnym do opisu „pedalskiego życia za czasów komunizmu", stwierdza w pewnym momencie, że być może należy tak często powtarzać te nieparlamentarne, nienadające się do druku słowa, aż zostaną one „wyprane” i przestaną szokować. Rzeczywiście: ta wulgarność słabnie stopniowo w trakcie lektury, przekład angielski niestety już od początku oferuje nam wersję light. W tłumaczeniu wulgaryzmów, podobnie jak nazw własnych, Martin znowu nie jest konsekwentny, ale i w tym wypadku wybrane rozwiązanie zdaje się odpowiednie: zastępowanie każdej formy słowa „kurwa” angielskim fuck lub bitch i każdej „pizdy” - cunt niebezpiecznie zbliżałoby wypowiedzi bohaterek do karykatury języka amerykańskich filmów, jako że wymienione wyzwiska i przekleństwa w dużym stopniu spowszechniały i zakorzeniły się w obecnej kulturze masowej. A przecież cioty z Lubiewa nie mówią współczesnym językiem. Ani tym telewizyjnym, ani internetowym, lecz cytatami z literatury polskiej czy popkultury okresu komunizmu. Decydując się na takie thumaczenie, Martin maksymalnie wykorzystuje możliwości języka angielskiego w zakresie wulgaryzmów (wymieńmy chociażby: whore, slapper, tart, slut, slag, snatch i pełen repertuar określeń ejakulatu: sperm, jism, cum, load itd.). Tym samym doskonale wpisuje się $\mathrm{w}$ (nomen omen) oralny charakter prozy Michała Witkowskiego.

Należy przy tym zauważyć, że nadrzędną strategią tłumaczeniową Martina jest unikanie swoistej kolonizacji tekstu. Tłumacz raczej egzotyzuje niż udomawia, nie zmienia nazw sklepów (jedyny wyjątek stanowi tu bodajże „Żabka”, zupełnie niepotrzebnie przełożona na „Frog Mart”), papierosów, lekarstw, gazet („Polityka”, „Nie”), chętnie pozostaje przy polskich określeniach odnoszących się do rzeczywistości stricte polskiej - typu 
„linijka” (jako rodzaj powozu) czy „oranżada”, jedynie momentami dookreśla wybrane terminy („,socialist apartment block, circa 1960" to blok gomułkowski - Lv, s. 3). Martin nie stosuje w zasadzie żadnych przypisów (oprócz objaśniających rosyjskie czy niemieckie dialogi, a także pojedyncze zwroty obcojęzyczne, którymi posługują się ciotki, jako że zapis fonetyczny w znacznym stopniu uniemożliwiałby identyfikację danej frazy), stąd konieczność lawirowania między wiernością wobec oryginału a czytelnością tekstu - ułatwiania lektury czytelnikowi. Tym samym próbuje znaleźć równowagę pozwalającą na zachowanie elementów kultury źródłowej, a jednocześnie nie alienować czytelników i czytelniczek. Niemniej brak przypisów skutkuje całkowitym zatarciem pewnych kontekstów (cytatów z piosenek, filmów, książek, kpin $\mathrm{z}$ wartości narodowych, $\mathrm{w}$ tym dorobku kulturowego, a więc całej sieci intertekstów) i wymagających ich znajomości żartów. Tłumacz nie może ich zastąić cytatami $\mathrm{z}$ kultury docelowej, z drugiej strony natomiast - nie powinien również zbytnio dostosowywać się do czytelnika przez liczne objaśnienia, oba te rozwiązania implikują bowiem imperialne nastawienie thumaczenia.

Mimo ogólnie bardzo udanego przekładu Martin oczywiście nie uniknął też błędów. Mniejszych, w zasadzie niewpływających na interpretację całości, przykładowo: „śnieżenie” obrazu to nie to samo co ghost images; klipsy, które kradnie Dżesi, by udawać Alexis, to nie hairslides, lecz clip earrings; zdanie „[But] I'm nobody's streetwalker" (Lv, s. 8) to dokładne odwrócenie znaczenia „Kurwą ci jestem nie lada” (Lb, s. 4). Wreszcie „wciskać język w szyję, w węzły chłonne, chłonąć” (Lb, s. 121) w przekładzie Martina to „sticking [...] tongue down a bloke's throat, right into the lymph nodes, siphonning them up" (Lv, s. 128), co wydaje się wręcz czynnością niemożliwą, nawet dla tak doświadczonych ciot (do głosu dochodzi tu klasyczna opozycja wewnętrzne - zewnętrzne, w tym wypadku gardło - szyja). Zdarzają się jednak i błędy większe - w pewnych momentach tłumacz, jakby zupełnie dowolnie, zmienia płeć bohaterów/bohaterek, na przykład z Andzi robiąc Andrzeja. Ponadto jednym z zarzutów „heteryków całą gębą” wobec ciot jest „niewierność” (Lb, s. 273), którą Martin przekłada jako lack of Polishness (Lv, s. 305). To dość poważne przeoczenie, cioty są bowiem na wskroś polskie, to one uosabiają lokalność kultury, to one najbardziej tęsknią za tym, co z polskością związane: „Wtedy to w ogóle bardziej się czuło, że się jest w Polsce. Bo były polskie produkty, w radio puszczali polską muzykę [...]. I człowiek czuł się Polakiem” (Lb, s. 93)- jak wspomina jedna $\mathrm{z}$ emerytek. 
Przekład tytułu także może wzbudzać kontrowersje, przede wszystkim dlatego, że Lubiewo to prawdziwa miejscowość ${ }^{8}$. Wprawdzie sama nazwa odnosi się według Witkowskiego do słów „lubieżność”, „lubieżny”, jednak skojarzenia z любить і любимыıй, zwłaszcza w kontekście innych rusycyzmów i rusofilii dostrzegalnej w książce, uzasadniają decyzję Martina. Co ciekawe, ten wybór tłumacza zdaje się wpływać na recepcję książki: „Love in the time of Communism: a rich, colourful novel about the perils and pleasures of being gay and coming out from behind the iron curtain, from Poland's answer to Almodovar" 9.

W Polsce nie istnieje właściwie kategoria „powieść gejowska”. Co prawda etykieta ta bywa używana w dyskursie akademickim, ale nie ma odbicia w rzeczywistości wydawniczej. Należy także pamiętać, w jakim kontekście historyczno-społecznym Lubiewo powstało. Przede wszystkim z jednej strony mamy lata rządów partii prawicowej i zakaz organizacji warszawskiej Parady Równości, a z drugiej euroentuzjazm i kampanię „Niech nas zobaczą" (2003). Znamienna jest również ówczesna recepcja Lubiewa: obok zachwytów pojawiły zatroskane głosy zmartwionych potencjalnie szkodliwym dla społeczności LGBT wydźwiękiem powieści oraz tych, których denerwowała implikowana homofobia pierwszych. Pamiętajmy przy tym, że Polska nie doświadczyła łączenia się ruchów wykluczonych w latach 60., nie ma też swojego odpowiednika Stonewall czy Raportu Wolfendena (trudno za taki uznać akcję Hiacynt, ponieważ konsekwencje tejże były zupełnie inne, w zasadzie - żadne) ani rewolucji seksualnej lat 70. Przejście od PRL-owskich ciot do wyemancypowanych gejów ukazane w Lubiewie Witkowskiego to przeskok sztuczny, który skutkuje równoległym funkcjonowaniem dwóch zupełnie odmiennych dyskursów, ciotowskiego i gejowskiego. Tłumacz musi więc sięgnąc po dwa odrębne paradygmaty. Dla czytelniczki/czytelnika z kraju anglojęzycznego Lubiewo jest pewnym novum, ale ze względu na sposób mówienia nie tyle o - brak lepszego słowa - homoseksualności, ile raczej o komunizmie i sytuacji krajów wschodnich tego okresu, o reperkusjach zarówno samego systemu, jak i jego obalenia. A ciota to nostalgiczne przypomnienie tego, co utracono w nowoczesnym queerze - czyli aspektu cielesności oraz lubieżności właśnie.

By podsumować nasze rozważania, przytoczmy kilka fragmentów z recenzji Lovetown:

${ }^{8}$ Zdaje się, że tylko tłumaczka przekładu hiszpańskiego zdecydowała się na podobny krok, reszta tłumaczeń konsekwentnie trzyma się tytułu Lubiewo.

9 Źródło: http://www.worldbooks.com/lovetown-by-michal-witkowski-522602.html, dostęp: 12 maja 2014. 
Michal Witkowski's book is not a novel but a series of pieces describing different lives. It makes clear that concepts of sexuality vary between societies, so that simply importing Western European concepts of sexual liberation isn't necessarily the way forward elsewhere in the world. It also reflects the general disappointment in Eastern Europe with what the free market has meant in practice ${ }^{\mathrm{IO}}$.

A fascinating look at how the darkness of communism may have only given way to a blander, cosmopolitan life for all and sundry ${ }^{\mathrm{II}}$.

A boisterous journey through communist and post-communist Poland. It's a riotous, anarchic, self-proclaimed „faggot Decameron" - a cacophony of voices that proudly recount their queer exploits in toilets, parks and army barracks before homosexuality was decriminalised ${ }^{\mathrm{T} 2}$.

Witkowski chose [...] to base his novel around the political changes of the 1980s, and their impact on gay men's lives. Instead of merely disinterring a period that seemed crude or repressed, Witkowski allows his dissident voices to challenge the notion that capitalism has benevolently triumphed in Poland, bringing prosperity and also every accompanying gay bauble to a backward people. [...] $[S]$ trident, surprisingly beautiful novel ${ }^{\mathrm{T} 3}$.

Jak widać, tym, na czym najbardziej skupia się uwaga odbiorcy docelowego, jest przemiana systemowa i jej konsekwencje. Dlatego też przyjęta przez Martina strategia thumaczenia powoduje, że w efekcie czytelnicy otrzymują naprawdę udany przekład. Przekład dziwacznej, queerowej, powieści, której osobliwość związana jest przede wszystkim z polskością i lokalnością. To, co u nas, czyli tu, czytane było (i nadal jest) głównie z perspektywy genderowo-queerowej, tam przywołuje aspekt postzależnościowy, jak i świeże spojrzenie na kwestie seksualności - poza dyskursem asymilacji (który to w Polsce w zasadzie nawet jeszcze się na dobre nie rozpoczął).

то Źródło: http//www.socialistreview.org.uk/article.php?artidenumber= 11227, dostęp: 12 maja 2014. 2014.

II Źródło: http://www.portobellobooks.com/lovetown, dostęp: 12 maja

I2 Źródło: http://www.theguardian.com/books/2010/mar/14/where-serpent-lives-templegoers-lovetown, dostęp: 12 maja 2014. Trzeba też zwrócić uwagę na niedopatrzenie recenzentki: depenalizacja homoseksualizmu w Polsce to $1932 \mathrm{r}$.

${ }_{3}$ Żródło: http://www.independent.co.uk/arts-entertainment/books/ revievs/lovetown-by-michal-witkowski-trans-w-martin-1972546.html, dostęp: 12 maja 2014. 
Autor przytoczonej powyżej recenzji przekładu Lubiewa opublikowanej w „The Independent”, Richard Canning, na samym wstępie swojego tekstu stawia pytanie, czy zachodnia literatura jest w stanie powiedzieć coś nowego o gejach, czy ten temat został już wyczerpany. My możemy zadać pytanie podobne, mianowicie - czy można coś jeszcze powiedzieć o Lubiewie. W obu przypadkach odpowiedź brzmi: tak. Tym wspólnym nowym „czymś” jest właśnie przekład literacki, traktowany jako zjawisko międzykulturowe, mające wpływ na literaturę nie tylko kraju, z którego pochodzi thumaczenie, ale także tego, do którego ów przekład trafia; kulturze docelowej bowiem daje możliwość poznania obcego świata, a źródłowej - spojrzenia na siebie samą oczami Innego. Oba te zjawiska reinterpretują dane kultury, mają więc dla każdej z nich znaczenie ontologiczne i epistemologiczne. I bez wątpienia w przypadku Lovetown osiągnięcie tego efektu jest zasługą świetnego przekładu Billa Martina. Pozostaje więc czekać na tłumaczenie Drwala -swego rodzaju kontynuacji omawianej tu powieści.

\section{ALEKSANDRA SZYMII}

\section{Lovetown. Some remarks on the Englih translation of Lubiewo}

The article is an analysis of the English translation of Michał Witkowski's Lubiewo, the translation first published in 2010 as Lovetown. The discussion focuses on the level of difficulty facing the translator, Bill Martin, in the context of numerous intertextual references in Lubiewo, the problem of memory and post-dependency. It is also an attempt at inquiry into the influence of translator's decisions on the reception of the novel abroad. In particular, the question of translation of the aesthetic of bent and camp in the text, which is visible in theatric quality of language, use of emotionally marked expressions, hyperboles, sexual undertones, sexual language proper, language games, gay slang etc.

Keywords: Lubiewo, Lovetown, camp, sexual language.

Aleksandra Szymil - doktorantka na Wydziale Filologii Polskiej i Klasycznej UAM, studentka kulturoznawstwa Wydziału Nauk Społecznych UAM, tłumaczka. Interesuje się przede wszystkim translatologią, przekładem literackim, studiami genderowymi i fanowskimi. Współautorka artykułu Science of deduction vs sztuka dedukcji, czyli Sherlock Holmes po polsku (2013). 